\title{
GAMBARAN PROFIL LIPID PADA SISWA OBESE DI SMP NEGERI 1 MANADO
}

\author{
${ }^{1}$ Astrid Noviera Iksan \\ ${ }^{2}$ Aaltje Manampiring \\ ${ }^{2}$ Fatimawali
}

\author{
${ }^{1}$ Kandidat Skripsi Fakultas Kedokteran Universitas Sam Ratulangi \\ ${ }^{2}$ Bagian Kimia Fakultas Kedokteran Universitas Sam Ratulangi Manado \\ Email : astridiksan@gmail.com
}

\begin{abstract}
Obesity is an abnormal condition of fat accumulation that can disrupt our health. Obesity problem experienced by some groups of people, one of them is teenager. Blood lipid profile level in obesity children is similar to lipid profile in cardiovascular disease and obesity children also had higher risk of hypertension. Lipid profile is a condition of blood lipid observed by cholesterol total such as LDL, HDL and triglyceride. According to International Diabetes Federation (IDF) criteria, obesity categorized if waist circumference $\geq 90 \mathrm{~cm}$ for male and $\geq 80$ for female. The objective is to determine overview of lipid profile in obese student of SMP Negeri 1 Manado. The research used observational method with cross sectional study, which obesity measured by waist circumference and laboratory results of blood lipid profile level.Based on the waist circumference in 371 populations, there were 97 students included to obesity category and by 97 students, only 13 obesity students took part in the research. There were $2(15,3 \%)$ students had total cholesterol level above normal, 3 (23,1\%) students had LDL level above normal, $1(7,7 \%)$ student had HDL level below normal and $2(15,4 \%)$ students hadtriglyceride level above normal.
\end{abstract}

Keywords: obesity, student, adolescents, lipid profile, SMP Negeri 1 Manado

\begin{abstract}
Abstrak: Obesitas merupakan keadaan abnormal penumpukan lemak yang dapat mengganggu kesehatan. Masalah obesitas banyak dialami oleh beberapa golongan masyarakat salah satunya remaja. Kadar profil lipid darah pada anak obesitas menyerupai profil lipid pada penyakit kardiovaskular dan anak yang obesitas mempunyai risiko hipertensi lebih besar. Profil lipid adalah keadaan lemak darah yang ditinjau dari kandungan total kolestrol dalam darah, LDL, HDL dan Trigliserida. Sesuai kriteria International Diabetes federation (IDF) dikategorikan obesitas jika nilai lingkar pinggang $\geq 90 \mathrm{~cm}$ untuk laki-laki dan $\geq 80 \mathrm{~cm}$ pada perempuan. Penelitian ini bertujuan untuk mengetahui gambaran profil lipid pada siswa obesitas di SMP Negeri 1 Manado.Penelitian dilakukan menggunakan metode observasional dengan desain crosssectional study, dimana obesitas diukur berdasarkan lingkar pinggang dan kadar profil lipid di periksa di laboratorium. Berdasarkan hasil pemeriksaan lingkar pinggang pada 371 populasi didapatkan 97 siswa termasuk dalam kategori obesitas dan dari 97 siswa tersebut hanya 13 siswa yang bersedia untuk melakukan pemeriksaan profil lipid. Dari hasil pemeriksaan tersebut didapatkan 2 (15.3\%) siswa obesitas memiliki kadar kolestrol total diatas normal, 3 (23.1\%) siswa obesitas memiliki kadar LDL diatas normal, 1 (7.7\%) siswa obesitas memiliki kadar HDL dibawah normal, dan 2 (15.4\%) siswa obesitas memiliki kadar Trigliserida diatas normal.
\end{abstract}

Kata Kunci : obesitas, siswa, remaja, profil lipid, SMP Negeri 1 Manado 
Obesitas saat ini menjadi masalah kesehatan di Indonesia, terutama di kotakota besar. ${ }^{1}$ Menurut (World Health Organization) WHO, obesitas merupakan keadaan abnormal penumpukan lemak yang dapat mengganggu kesehatan. ${ }^{2}$ Secara fisiologis, obesitas didefinisikan sebagai suatu kondisi akumulasi lemak yang tidak normal atau berlebihan di jaringan adiposa sampai kadar tertentu sehingga dapat merusak kesehatan. ${ }^{3}$ Menurut Krisma, ${ }^{3}$ seseorang yang memiliki berat badan 20\% lebih tinggi dari nilai tengah kisaran berat badannya yang normal dianggap mengalami obesitas. Masalah obesitas banyak dialami oleh beberapa golongan masyarakat salah satunya remaja. Masalah gizi pada remaja timbul karena perilaku gizi yang salah yaitu ketidakseimbangan antara konsumsi gizi dengan kecukupan gizi dianjurkan. ${ }^{5}$ Di Indonesia ditemukan prevalensi obesitas sebesar 9,7 \% di Yogyakarta, 10,6 \% di Semarang dan 15,8 $\%$ di Denpasar. Pada penelitian di Kota Tomohon dan Tondano pada tahun 2010 masing-masing kota memiliki prevalensi obesitas yang tinggi pada usia remaja masing-masing $35 \%$ dan 38,2 \%. ${ }^{3,4}$ Hasil Riset Kesehatan Dasar (Riskesdas) tahun 2013 menyatakan prevalensi gemuk naik dari 1,4 persen (2007) menjadi 7,3 persen (2013) untuk remaja berumur 16-18 tahun. ${ }^{6}$

Beberapa faktor penyebab obesitas pada anak usia sekolah antara lain asupan makanan berlebihan yang berasal dari jenis makanan jajanan seperti makanan cepat saji (burger, pizza, hot dog) dan makanan siap saji lainnya yang tersedia di gerai makanan. Faktor penyebab lainnya adalah kurang aktivitas fisik baik kegiatan harian maupun latihan fisik terstruktur. ${ }^{8}$ Penelitian lain juga menyatakan bahwa kegemukan dapat diturunkan, sehingga memungkinkan orang tua yang gemuk memiliki anak yang gemuk juga. $^{2}$

Profil lipid adalah keadaan lemak darah yang ditinjau dari kandungan total kolestrol dalam darah , LDL, HDL dan Trigliserida. $^{10}$ Displidemia pada anak obesitas harus dievaluasi sejak dini.
Menurut Hidayati dan Siti, kadar profil lipid darah pada anak obesitas menyerupai profil lipid pada penyakit kardiovaskular dan anak yang obesitas mempunyai risiko hipertensi lebih besar. ${ }^{1,11}$ Pembentukan aterosklerosis berhubungan dengan lipid dalam darah. ${ }^{10}$ Faktor resiko terjadi penyakit jantung koroner di Indonesia akibat Displidemia antara 7-17 \% dengan rata-rata kadar kolestrol antara 203-213 mg/dl. ${ }^{9} \quad$ Riset Kesehatan Dasar (RISKESDAS) tahun 2013 menyatakan penduduk di Indonesia tahun 2013 dengan kisaran umur $\geq 15$ tahun memiliki kadar kolesterol total di atas nilai normal sebesar 35,9 \%, kadar HDL dibawah normal 22,9 $\%$, kadar LDL diatas nilai normal dengan kategori near optimal dan borderline $60,3 \%$, kategori tinggi dan sangat tinggi $15,9 \%$. Serta kadar trigliserida kategori borderline tinggi 13,0 \% versus 11,9\% untuk kategori tinggi dan sangat tinggi. ${ }^{6}$

\section{METODE PENELITIAN}

Penelitian ini dilakukan dengan menggunakan metode cross sectional (potong lintang). Penelitian dilaksanakan di SMP Negeri 1 Manado. Waktu penelitian mulai bulan November 2014 sampai Januari 2015. Populasi adalah seluruh siswa kelas 1-3 SMP Negeri 1 Manado yang berusia 11-14 tahun. Sampel adalah siswa SMP Negeri 1 Manado. Pengambilan sampel menggunakan cara Simple Random Sampling. Kriteria Inklusi adalah siswa yang berusia 11-14 tahun, sehat, terdaftar dan aktif mengikuti kegiatan disekolah. Siswa yang bersedia menandatangani surat persetujuan untuk dijadikan sampel penelitian dan telah berpuasa selama 10 12 jam. Kriteria Eksklusi adalah siswa yang berusia 11 - 14 tahun yang tidak bersedia menandatangani surat persetujuan dan siswa yang sedang atau pernah menderita penyakit berat. Definisi Operasional profil lipid yaitu dinilai keadaan lemak darah yang ditinjau dari kandungan total kolestrol dalam darah $(\geq 200 \mathrm{mg} / \mathrm{dL})$, LDL $(\geq 130$ $\mathrm{mg} / \mathrm{dL}), \quad \mathrm{HDL} \quad(<40 \mathrm{mg} / \mathrm{dL})$ dan Trigliserida $(\geq 150 \mathrm{mg} / \mathrm{dL})$. Obesitas dinilai 
dari pengukuran lingkar pinggang. Tempat pengukuran diantara tulang panggul bagian atas dan tulang rusuk bagian bawah. Kategorian obesitas berdasarkan nilai lingkar pinggang, untuk laki-laki $>90 \mathrm{~cm}$, dan untuk wanita $>80 \mathrm{~cm}$ (International Diabetes Federation, 2007).

\section{HASIL PENELITIAN}

Penelitian ini dilakukan sejak bulan November 2014 sampai bulan Januari 2015 di SMP Negeri 1 Manado. Penelitian diawali dengan membuat surat izin penelitian yang di tanda-tangani Kepala Bagian Kimia Fakultas Kedokteran Universitas Sam Ratulangi dan diserahkan kepada Kepala Sekolah SMP Negeri 1 Manado.

Subjek dalam penelitian ini adalah remaja yang berusia 11-14 tahun yang merupakan siswa SMP Negeri 1 Manado kelas 7 sampai 9.

Tabel 1. Prevalensi obesitas siswa SMP Negeri 1 Manado

\begin{tabular}{cccccc}
\hline No & $\begin{array}{c}\text { Jenis } \\
\text { kelamin }\end{array}$ & $\mathrm{N}$ & \multicolumn{3}{c}{ Lingkar Pinggang } \\
\cline { 3 - 6 } & $\mathrm{L}$ & 176 & $\begin{array}{c}\text { Normal } \\
(\%)\end{array}$ & $\begin{array}{c}\text { Obesitas } \\
(\%)\end{array}$ & $\%$ \\
\hline 1 & $\mathrm{P}$ & $135,1 \%)$ & $\begin{array}{c}44 \\
(11,9 \%)\end{array}$ & 100 \\
\hline 2 & 195 & $\begin{array}{c}143 \\
(38,8 \%)\end{array}$ & $\begin{array}{c}53 \\
(14,2 \%)\end{array}$ & 100 \\
\hline & \multirow{2}{*}{ Total } & 371 & $\begin{array}{c}274 \\
(73,9 \%)\end{array}$ & $\begin{array}{c}97 \\
(26,1 \%)\end{array}$ & 100 \\
\hline
\end{tabular}

Pada Tabel 1. Menunjukan dari 371 remaja yang diukur lingkar pinggang berusia 11-14 tahun didapatkan 97 orang siswa yang mengalami obesitas dengan presentasi 26,1 \% yang terdiri dari 44 remaja laki-laki dengan presentase 11,9\% dan 53 remaja perempuan dengan presentase $14.2 \%$.

Tabel 2, 4, 5. Menunjukan dari 97 orang siswa dilakukan pengambilan darah terhadap 13 orang siswa yang telah bersedia untuk dijadikan sampel. Dari hasil pengambilan tersebut diperoleh 1 siswa memiliki kadar kolestrol total diatas nilai normal dengan kategori Tinggi $(\geq 240$ mg/dL) dan 1 siswa termasuk Batas Tinggi (200-239 mg/dL) dengan presentase 15,3\%. 1 siswa memiliki kadar LDL diatas nilai normal kategori Batas Tinggi (130-159 $\mathrm{mg} / \mathrm{dL}$ ) dan 2 siswa kategori Sangat Tinggi ( $\geq 190 \mathrm{mg} / \mathrm{dL}$ ) dengan presentase 23,1\%. 1 siswa memiliki kadar HDL yang dibawah nilai normal dengan kategori Low $(\leq 40$ $\mathrm{mg} / \mathrm{dL}$ ) dengan presentase 7,7\%. Serta 2 siswa memiliki kadar Trigliserida diatas nilai normal $(\geq 150 \mathrm{mg} / \mathrm{dL})$ dengan presentase $\quad 15.4 \quad \%$. 
Iksan, Manampiring, Fatimawali: Gambaran profil Lipid...

Tabel 2. Kadar Kolestrol Total untuk siswa obesitas (Kategori NCEP 2011)

\begin{tabular}{ccccc}
\hline Nama & JK & Umur & $\begin{array}{c}\text { Lingkar } \\
\text { Pinggang } \\
(\mathrm{cm})\end{array}$ & $\begin{array}{c}\text { Kolestrol Total } \\
\text { (mg/dL) }\end{array}$ \\
\hline DR & $\mathrm{P}$ & 13 & 90 & $256^{*}$ \\
CM & $\mathrm{P}$ & 12 & 83 & 170 \\
TM & $\mathrm{P}$ & 14 & 87 & 162 \\
RN & $\mathrm{L}$ & 13 & 103 & 163 \\
RH & $\mathrm{L}$ & 12 & 99 & 196 \\
DS & $\mathrm{L}$ & 13 & 93 & 147 \\
MI & $\mathrm{L}$ & 13 & 92 & 143 \\
SO & $\mathrm{P}$ & 13 & 87 & 164 \\
AM & $\mathrm{L}$ & 13 & 97 & $217^{* *}$ \\
AU & $\mathrm{L}$ & 14 & 91 & 115 \\
NP & $\mathrm{P}$ & 14 & 82 & 141 \\
YA & $\mathrm{L}$ & 13 & 92 & 171 \\
CTR & $\mathrm{P}$ & 13 & 84 & 158 \\
\hline
\end{tabular}

Ket : $\left(^{*}\right)$ Kategori Tinggi ; $\left({ }^{* *}\right)$ Kategori Batas Tinggi

Tabel 3. Kadar LDL untuk siswa obesitas (Kategori NCEP 2011)

\begin{tabular}{clccc}
\hline Nama & JK & Umur & $\begin{array}{c}\text { Lingkar } \\
\text { Pinggang } \\
(\mathrm{cm})\end{array}$ & $\begin{array}{c}\text { LDL } \\
\text { (mg/dL) }\end{array}$ \\
\hline DR & $\mathrm{P}$ & 13 & 90 & $201^{*}$ \\
CM & $\mathrm{P}$ & 12 & 83 & 118 \\
TM & $\mathrm{P}$ & 14 & 87 & 121 \\
RN & $\mathrm{L}$ & 13 & 103 & 116 \\
RH & $\mathrm{L}$ & 12 & 99 & $136^{* *}$ \\
DS & $\mathrm{L}$ & 13 & 93 & 99 \\
MI & $\mathrm{L}$ & 13 & 92 & 77 \\
SO & $\mathrm{P}$ & 13 & 87 & 110 \\
AM & $\mathrm{L}$ & 13 & 97 & $153^{* *}$ \\
AU & $\mathrm{L}$ & 14 & 91 & 106 \\
NP & $\mathrm{P}$ & 14 & 82 & 85 \\
YA & $\mathrm{L}$ & 13 & 92 & 108 \\
CTR & $\mathrm{P}$ & 13 & 84 & 102 \\
\hline
\end{tabular}

Ket : $\left(^{*}\right)$ Kategori Sangat Tinggi ; $(* *)$ Kategori Batas Tinggi

\section{BAHASAN}

Penelitian ini dilakukan pada bulan november 2014 dengan menggunakan sampel siswa SMP Negeri 1 Manado, pada awal penelitian peneliti terlebih dahulu membuat surat pengantar penelitian yang telah ditanda tangani oleh Kepala Bagian Kimia Fakultas Kedokteran Universitas Sam Ratulangi, surat tersebut kemudian diserahkan kepada Kepala Sekolah SMP Negeri 1 Manado untuk mendapatkan izin penelitian. Pada penelitian yang mengambil sampel 371 siswa SMP Negeri 1 Manado yang berusia 11-14 tahun yang dipilih secara acak diperoleh 97 orang termasuk dalam kategori obesitas (26.1\%). 
Jurnal e-Biomedik (eBm), Volume 3, Nomor 1, Januari-April 2015

Tabel 4. Kadar HDL untuk siswa obesitas (Kategori IDF 2007)

\begin{tabular}{ccccc}
\hline Nama & JK & Umur & $\begin{array}{c}\text { Lingkar } \\
\text { Pinggang } \\
\text { (cm) }\end{array}$ & $\begin{array}{c}\text { HDL } \\
\text { (mg/dL) }\end{array}$ \\
\hline DR & P & 13 & 90 & 52 \\
CM & P & 12 & 83 & 47 \\
TM & P & 14 & 87 & 41 \\
RN & L & 13 & 103 & 43 \\
RH & L & 12 & 99 & 53 \\
DS & L & 13 & 93 & 47 \\
MI & L & 13 & 92 & 60 \\
SO & P & 13 & 87 & $38^{*}$ \\
AM & L & 13 & 97 & 50 \\
AU & L & 14 & 91 & 40 \\
NP & P & 14 & 82 & 50 \\
YA & L & 13 & 92 & 53 \\
CTR & P & 13 & 84 & 53 \\
\hline
\end{tabular}

Ket : $(*)$ Kategori Dibawah Nilai Normal

Tabel 5. Kadar Trigliserida untuk siswa obesitas (Kategori IDF 2007)

\begin{tabular}{ccccc}
\hline Nama & JK & Umur & $\begin{array}{c}\text { Lingkar } \\
\text { Pinggang } \\
(\mathrm{cm})\end{array}$ & $\begin{array}{c}\text { Trigliserida } \\
(\mathrm{mg} / \mathrm{dL})\end{array}$ \\
\hline DR & $\mathrm{P}$ & 13 & 90 & 73 \\
CM & $\mathrm{P}$ & 12 & 83 & 110 \\
TM & $\mathrm{P}$ & 14 & 87 & 86 \\
RN & $\mathrm{L}$ & 13 & 103 & 102 \\
RH & $\mathrm{L}$ & 12 & 99 & $153^{*}$ \\
DS & $\mathrm{L}$ & 13 & 93 & 63 \\
MI & $\mathrm{L}$ & 13 & 92 & 57 \\
SO & $\mathrm{P}$ & 13 & 87 & $170^{*}$ \\
AM & $\mathrm{L}$ & 13 & 97 & 94 \\
AU & $\mathrm{L}$ & 14 & 91 & 70 \\
NP & $\mathrm{P}$ & 14 & 82 & 61 \\
YA & $\mathrm{L}$ & 13 & 92 & 68 \\
CTR & $\mathrm{P}$ & 13 & 84 & 54 \\
\hline
\end{tabular}

Ket : $(*)$ Kategori Diatas Nilai Normal

Tabel 6. Statistik hasil penelitian siswa obesitas

\begin{tabular}{cccccc}
\hline Profil & Rata-rata & Min & Max & Median & St. Deviasi \\
Lipid & & & & & \\
\hline KT & 169,4 & 115 & 256 & 163 & 36,2 \\
LDL & 48,2 & 38 & 60 & 50 & 6,3 \\
HDL & 117,8 & 77 & 201 & 110 & 31,9 \\
TG & 89,3 & 54 & 170 & 73 & 36,6 \\
\hline
\end{tabular}


Terdapat 44 laki-laki (11.9\%) dan 53 perempuan (14.2\%) yang termasuk dalam kategori obesitas.

Dari 97 orang siswa dilakukan pengambilan darah terhadap 13 orang siswa yang telah bersedia untuk dijadikan sampel. Dari hasil pengambilan tersebut diperoleh prevalensi siswa memiliki kadar kolestrol total diatas nilai normal dengan kategori Tinggi $(\geq 240 \mathrm{mg} / \mathrm{dL})$ dan Batas Tinggi (200-239 mg/dL) adalah 15,3\%. Prevalensi siswa memiliki kadar LDL diatas nilai normal adalah 23,1\% dengan kategori Batas Tinggi (130-159 mg/dL) dan kategori Sangat Tinggi $(\geq 190 \mathrm{mg} / \mathrm{dL})$. Prevalensi siswa memiliki kadar HDL yang dibawah nilai normal dengan kategori Low $(\leq 40$ $\mathrm{mg} / \mathrm{dL}$ ) adalah 7,7\%. Prevalensi siswa memiliki kadar Trigliserida diatas nilai normal ( $\geq 150 \mathrm{mg} / \mathrm{dL}$ ) adalah $15.4 \%$.

Berdasarkan hasil riset yang diperoleh Riset kesehatan Dasar (RISKESDAS) 2013 yang dikeluarkan kementrian kesehatan ditemukan bahwa prevalensi obesitas berdasarkan indikator lingkar perut pada remaja dengan usia $\geq 15$ tahun sebesar 26.6 $\%{ }^{6}$ Hasil ini pun didukung dengan penelitian yang telah dilakukan di SMP Negeri 1 Manado. Dari penelitian tersebut diperoleh prevalensi obesitas sebesar 26.1 \% dengan perbandingan $11.9 \%$ pada lakilaki dan 14.2 \% pada perempuan dimana sesuai juga dengan penelitian Wulan Tuerah tahun 2012 didapat perbandingan lebih besar $9.5 \%$ pada perempuan dan 2.91 $\%$ pada laki-laki. ${ }^{12}$

Sesuai letak SMP Negeri1 Manado di tengah kota dengan memiliki banyak kantin di dalam sekolah maupun di luar sekolah membuat siswa cenderung makan makanan cepat saji seperti burger, pizza, hot dog ataupun gorengan. Pada umumnya, makanan cepat saji ini mengandung lemak dan garam tinggi dengan kandungan serat yang rendah. ${ }^{13}$

Obesitas pada masa anak berisiko tinggi menjadi obesitas dewasa dan berpotensi tinggi mengalami penyakit metabolik dan penyakit degeneratif dikemudian hari. Profil lipid pada anak obesitas menyerupai profil lipid pada penyakit kardiovaskular dan anak yang obesitas mempunyai risiko hipertensi lebih besar. ${ }^{11}$ Terdapat hubungan erat anatara kadar kolestrol total atau kolestrol LDL dalam plasama dan penyakit jantung koroner. $^{14}$

Dari 13 siswa obesitas yang bersedia menjadi sampel pengambilan darah, terdapat $23.1 \%$ siswa yang memiliki kadar LDL melebihi nilai normal. Angka ini bisa dibilang cukup tinggi. $23.1 \%$ siswa obesitas ini bisa dissebut mengalami hiperkolestrolemia LDL. Hiperkolestrolemia LDL ini jika disertai dengan hipertrigliserida dan hipo-HDL bisa menyebabkan terjadinya Dislipidemia. Dislipidemia adalah kelainan metabolisme lipid yang ditandai peningkatan kolestrol total, kolestrol LDL, trigliserida di atas nilai normal serta penurunan kolestrol HDL di dalam darah. ${ }^{15}$

Bila dihubungkan dengan obesitas, secara fisiologis obesitas atau berat badan lebih didefinisikan sebagai suatu keadaan dengan akumulasi lemak yang tidak normal atau berlebihan dijaringan adiposa. Pembesaran adiposit ini menunjukkan peningkatan lipolitik, berperan dalam peningkatan asam lemak bebas melalui sirkulasi portal menuju hati. Kadar asam lemak bebas portal yang tinggi akan menstimulasi sintesis triasilgliserol di hati, yang akan diseksresikan dalam VLDL dan produksi apo-B yang merupakan protein utama di hati. Tingginya pembentukan VLDL tersebut dapat meningkatkan kadar LDL yang merupakan penguraian dari VLDL. ${ }^{16}$ Dari peningkatan kadar LDL umumnya bisa menyebabkan terjadi penumpukan lemak pada ruang subendotel pembuluh darah yang merupakan tanda awal adanya pertumbuhan plak aterosklerotik yang dikenal sebagai fatty streak. Aterosklerosis ini dapat mempersempit lumenpembuluh darah koroner sehingga aliran darah terganggu dan menurunkan elastisistas pembuluh darah tersebut. ${ }^{17}$ Plak-plak dipembuluh darah koroner tersebut akan 
semakin menyumbat dan menimbulkan penyakit jantung koroner.

Pola hidup juga dapat mempengaruhi kadar HDL. Dibuktikan pada penelitian Roya et al pada remaja dengan berat badan lebih dan obesitas. Setelah 4 bulan pola hisup responden dirubah, seperti mengurangi makan makanan fast food, sarapan teratur, dan meningkatkan aktivitas fisik di rumah dan sekolah, ternyata terjadi peningkatan kadar kolestrol HDL. ${ }^{18}$

Melalui penelitian yang dilakukan di SMP Negeri 1 Manado ini menunjukkan bahwa siswa SMP Negeri 1 Manado termasuk prevalensi obesitas tinggi karena anak sekolah cenderung konsumsi makan cepat saji yanumumnya mengandung lemak dan garam tinggi yang menyebabkan penumpukan lemak di jaringan adiposit sehingga merubah kadar profil lipid dalam darah.

\section{SIMPULAN}

Pada penelitian ini dapat disimpulkan berdasarkan hasil pemeriksaan lingkar pinggang pada 371 populasi didapatkan 97 (26,1 \%) siswa termasuk dalam kategori obesitas dan dari 97 siswa tersebut hanya 13 siswa yang bersedia untuk melakukan pemeriksaan profil lipid.

Hasil pemeriksaan profil lipid tersebut didapatkan 2 (15,3\%) siswa obesitas memiliki kadar kolestrol total diatas nilai normal, 3 (23,1\%) siswa obesitas memiliki kadar LDL diatas nilai normal, $1(7,7 \%)$ siswa obesitas memiliki kadar HDL dibawah nilai normal, dan 2 $(15,4 \%)$ siswa obesitas memiliki kadar Trigliserida diatas nilai normal

\section{SARAN}

Bagi remaja untuk dapat mengatur pola makan dan memperbanyak aktivitas fisik, amat terlebih bagi remaja obesitas, karena dengan ukuran berat badan yang lebih memiliki kecendrungan timbulnya berbagai macam pernyakit. Untuk orang tua dapat membantu anak dalam mengatur pola hidup sehat, juga membawa untuk mengontrol kadar profil lipid secara berkala guna menghindari penyakit ataupun komplikasi serius.

\section{UCAPAN TERIMA KASIH}

Penulis mengucapkan terima kasih kepada semua pihak yang turut serta menyumbang pikiran dalam penulisan artikel ini.

\section{DAFTAR PUSTAKA}

1. Hidayati SN, Hamam H, Lestari W. Hubungan asupan zat gizi \& imt dengan hiperlipidemia pada murid sltp yang obesitas di yogyakarta. Sari pediatri. 2006;8:25-31.

2. Chaula LS. Tatalaksana obesitas di subbagian bedah plastik rs dr.cipto mangkusumo. Maj kedokt indon. Maret 2007;57:86-90

3. Krisma JMT, Aaltje EM, Billy JK. Prevalensi obesitas pada remaja di smpn 8 manado. Jurnal e-biomedik. Juli 2014;2.

4. Donald AC, Aaltje EM, Fatimawali. Prevalensi obesitas pada remaja sma ypkm di kota manado. Jurnal ebiomedik. Juli 2014;2.

5. Muktiharti S, Purwanto, Purnomo I, Saleh R. Faktor resiko obesitas pada remaja sma negeri 2 dan sma negeri 3 di kota pekalongan tahun 2010. Pena medika. 2011;3.

6. Laporan hasil Riset Kesehatan Dasar (RISKESDAS) 2013. Badan Penelitian dan Pengembangan Kesehatan. Diunduh:22 September 2014

7. M Mexitalia, Agustini U. M Sakundarmo, et al. Sindroma metabolik pada remaja obesitas. M med indones. 2009;43:300-5

8. Sartika RAD. Faktor resiko obesitas pada anak 5-15 tahun di indonesia. Makara kesehatan. Juni 2011;15;3743.

9. Ahlian A. Perbedaan profil lipid darah asupan lemak normal dan lemak tinggi pada anak dengan obesitas usia 6-7 tahun. [disertasi]. [Semarang]: Universitas Diponegoro; 2005. 
10. Ercho NC. Hubungan obesitas dengan kadar ldl dan hdl pada mahasiswa preklinik fakultas kedokteran universitas lampung tahun 2013. 2014 Jul 24 [akses 2014 Sep 22]. Tersedia dari: http://digilib.unila.ac.id/id/eprint/24 32

11. Siti Nurul, Rudi I, Boerhan $\mathbf{H}$. Obesitas pada anak. Divisi Nutrisi Dan Penyakit Metabolic. Bagian/SMF Ilmu Kesehatan Anak FK Unair/RS dr. Soetomo Surabaya, 2006.

12. Wulan T. Prevalensi obesitas pada remaja di sma kristen tumou tou kota Bitung. Jurnal e-biomedik. Juli 2014;2:514-7

13. Ali K, Faisal A. Sehat itu mudah wujudkan hidup sehat dengan makanan tepat. Jakarta: Hikmah; Juni 2008. P.10.

14. David R, David W, John B.
Kedokteran klinis. Edisi 6. Jakarta: Erlangga; 2005. p.192

15. Laurenntia YS. Dislipidemia pada obesitas dan tidak obesitas di rsup dr.kaiadi dan laboratorium klinik swasta di kota semarang. Media medika muda. Agustus 2012.

16. Jonathan HS. Hubungan kadar kolestrol high density lipoprotein darah dengan kadar high sensitivity c-reactive protein pada remaja obes. Jurnal e-biomedik. Juli 2014.

17. Dawn B, Allan M, collen S. Biokimia kedokteran dasar: Sebuah pendekatan klinis. Jakarta: EGC; 2000. p.522-3

18. Ardanan Y. Gambaran kadar kolestrol low density lipoprotein darah pada mahasiswa angkatan 2011 fakltas kedokteran universitas sam ratulangi dengan indeks massa tubuh $\geq 23 \mathrm{kkg} / \mathrm{mg}^{2}$. Jurnal ebiomedik. Juli 2013;957 